\title{
EFFECTS OF SALICYLIC ACID AND SUCROSE SOLUTION ON VASE LIFE OF CUT Antigonon leptopus INFLORESCENCES AND THEIR POTENTIAL AS CUT FLOWERS FOR FLOWER ARRANGEMENT
}

\author{
HAIDAR HARIRI ABU SEMAN AND HUSNI HAYATI MOHD RAFDI*
}

School of Food Science and Technology, Universiti Malaysia Terengganu, 21030 Kuala Nerus, Terengganu, Malaysia

* Corresponding author: husni@umt.edu.my

\begin{abstract}
Pink Antigonon leptopus have potential to be commercialized as cut flowers for flower arrangement. In order to determine cut inflorescences' vase life, vase solution treatments containing Artificial Tap Water as control, salicyclic acid (SA) at 100, 200, $300 \mathrm{mg} / \mathrm{L}$ and combination of 100, $200,300 \mathrm{mg} / \mathrm{L}$ SA with $2 \%$ sucrose were conducted. Parameters observed were vase life, relative fresh weight (RFW), vase solution uptake (VSU), flower drop (FD), flower colour, relative water content (RWC) and $\mathrm{pH}$. The results showed that cut inflorescences in vase treatment containing 200 $\mathrm{mg} / \mathrm{L} \mathrm{SA}+2 \%$ sucrose and $300 \mathrm{mg} / \mathrm{L}+2 \%$ sucrose had 1.6 fold longer vase life than the control, showing higher water uptake and reduced flower drop by $28 \%$.
\end{abstract}

Keywords: Antigonon leptopus, salicylic acid, sucrose, tropical cut flowers, vase treatment

\section{Introduction}

Coral vines or Antigonon leptopus (A. leptopus) belong to the family of Polygonaceae (Sathi \& Habibur, 2013). A. leptopus are native to Mexico and cultivated as ornamentals for their showy flowers. They have been introduced across the tropics and are commonly found in America, Caribbean, Tropical Asia and Africa (Burke \& DiTommaso, 2011). A. leptopus produce small, beautiful and attractive flowers with bright pink or white in colour with showy characteristic (Adjaloo et al., 2015). The flowers have five petals and the diameter can reach between 0.4 to $2 \mathrm{~cm}$. The flowers are born in panicles, arranged in long with branching inflorescences that are quite striking as hanging over a trellis (Ranjan \& Tripathi, 2015).

There are some usefulness of A. leptopus especially in medicine. For example the tubers can be used as tonic and nutritious food (Sathi \& Habibur, 2013). Polygonaceae plants are known to be rich in phenolic compounds especially tannins (Balasubramani et al., 2014). In India, the leaves of coral vines are used to treat diabetes, menstrual pains, and hypertension; reduce swelling; and prevent cough and flu-related pains. The methalonic extract of coral vines has shown antithrombin activity (Balasubramani et al., 2014). The tubers and the flowers of A. leptopus are consumed as food components and used in the preparation of tea as cold remedy (Ranjan \& Tripathi, 2015). The root extracts have been found to show the properties of anti-inflammatory and analgestic associated with antimicrobial and antifungal activity. The flowers of A. leptopus contain flavonoids, which are antidiabetic in nature, and the plants are used as a hepatoprotective agent (Balasubramani et al. 2014). Besides that, the extracts of ethanol and chloroform from A. leptopus flowers are active against dental pathogen.

However, to date, the potential of A. leptopus as cut flowers for flower arrangement has not been explored. Although tropical flowers like A. leptopus may not be commercialized as cut flowers for bouquets due to several factors such as insufficient stem length $(\leq 40 \mathrm{~cm})$, there is a market for this kind of flowers mainly as flower arrangements for display at hotels or official events, and as flower arrangements at competitions or exhibitions. Floral arrangement is an art of choosing and organizing flowers and foliage according to the elements and principles of design in order to attain a pleasing and interesting design and arranging flowers is an artistic activity and a way to express oneself creatively (Baxter County Master Gardener, 2005). Floral arrangement is created from cut flowers, dried flowers and artificial flowers. Flower arrangement also is related to flower care, flower handling, floral design or arranging, merchandising and display and flower delivery (Baxter County Master Gardener, 2005). Hence, vase life of the cut A. leptopus and factors that influence it need to be studied first prior to their commercialization. Therefore, this study is an attempt to investigate the vase life of cut A. leptopus inflorescences and also their potential postharvest treatment.

Salicyclic acid (SA) is a plant hormone that plays an important role in inducing plant defence against a variety of biotic and abiotic stresses by morphological, physical 
and biochemical mechanisms that affect the plant growth and development (War et al., 2011). It is a phenolic compound which promotes photosynthesis under no stress condition (Nazar et al., 2015). Bayat \& Aminifard (2017) reported that in vase solution, $\mathrm{SA}$ could lower the $\mathrm{pH}$ of water and reduce the proliferation of bacteria. It also can affect biosynthesis of ethylene by suppressing 1aminoacyclopropane 1-carboxylate synthase (ACC synthase) and 1-aminocyclopropane-1-carboxylate oxidase (ACC oxidase) activities. SA with activating antioxidant enzymes delays the senescence of cut flowers and this preservative solution can lower lipid production per oxidation resulting in delay in senescence (Jamshidi et al., 2012). Hatamzadeh et al (2012) reported that treatment of $150 \mathrm{mg} / \mathrm{L} \mathrm{SA}$ was the most effective on vase life of cut Gladiolus grandiflora flowers whereby the concentration used could maintain antioxidant enzyme, higher spike fresh weight, stability of membrane, and delay of petal senescence lea to delay in senescence of flower, and reduced leakage of ion in petals, as well as decreased fresh weight loss and lipid peroxidation.

Sucrose is non-reducing sugar and an example of preservative that plays an important role to preserve the quality of cut flowers as it provides energy and occurs naturally in the plant parts in various amount (Dahal, 2013). Asrar (2012) reported that sucrose is the most common sugar used in prolonging vase life among all the different types of sugars. The sucrose in vase solution treatment can increase the mechanical rigidity of the stem and induce cell wall thickening and lignification of vascular tissue (Jafarpour et al., 2015) and it also antagonizes the effect of ABA, which promotes senescence (Sardoei \& Shahdadneghad, 2014). The continuous treatment with sucrose markedly promoted floret opening and extended the floret longevity in cut sweet peas and the vase life of florets treated with $100 \mathrm{~g} \mathrm{~L}^{-1}$ sucrose was 3 times longer than the control (Ichimura, 1998). Asrar (2012) reported that the combination of 200 ppm 8hydroxyquinoline sulfate (8-HQS) with $2 \%$ sucrose has shown positive impact on maintaining the quality of snapdragon (Antirrhinum majus L.) cut flowers, delaying flower senescence, enhancing post-harvest quality, increasing water uptake and water balance, increasing fresh weight of the cut flower stems and prolonging the vase life up to 18 days. Not only as vase solution, sucrose pulsing treatment also caused the increase in vase life of many cut flower species. For example, two cultivars of Rosa hybrida pulsed with sucrose at $25 \mathrm{~g} \mathrm{~mL}^{-1}$ could extend their vase life by 8.2 days in var. Whisk Mac and 7.5 days in var. Trika as compared to 5.3 days in the control (Butt, 2005). Orchids (Cymbidium hybrid 'Red Princess') treated with $5 \%$ sucrose pulsing had longer vase life of 56 days (De et al. 2014).
The combination of SA and sucrose has shown positive effect in reducing the respiration rate, alleviating moisture stress and improving the vase life of cut roses. Sardoei \& Shahdadneghad (2014) found that SA and sucrose increased vase life and fresh weight, and reduced stem curvature at the concentration of $4 \%$ sucrose $+800 \mathrm{mg} / \mathrm{L}$ SA while treatment containing $12 \%$ sucrose $+400 \mathrm{mg} / \mathrm{L}$ SA increased mean absorbed preservative solution. The inclusion of 100-300 mg/L SA and sucrose significantly extended the display life of five commercial cut flower species, (Alstroemeria peruvlana, Gerbera jasmesonii, Lillium asiaticum, Rosa hybrid and Polianthes tuberosa). The effect of SA was highly significant on fresh weight, with the SA of $300 \mathrm{mg} / \mathrm{L}$ having the highest effect among other treatments (Bayat \& Aminifard, 2017). The combination of SA and sucrose also led to a significant reduction in respiration rate and alleviated the moisture stress of cut roses to improve the vase life (Bayat and Aminifard, 2017).

Therefore this study was conducted to evaluate the vase life and factors influencing the vase life of cut A.leptopus. The combination of SA and sucrose as potential postharvest treatment for cut A. leptopus was also studied.

\section{Materials and Methods Experiment Location and Materials Plant Materials}

The experiment was conducted between September 2017 to May 2018 at the green house and at Crop Science Laboratory, School of Food Science and Technology, Universiti Malaysia Terengganu (UMT) $\left(5.4087^{\circ} \mathrm{N}\right.$, $\left.103.0888^{\circ} \mathrm{E}\right)$. Six polybags of A. leptopus seedlings were purchased from a supplier, Fitra Flora, in Kula Terengganu, Terengganu, Malaysia. The plants then were transplanted into six plastic pots with a measurement of 20 $\mathrm{cm}$ diameter $\times 27 \mathrm{~cm}$ height. The soil medium used was a mixture of top soil, sand and chicken dung at 3:1:1 ratio, respectively. Then, the A. leptopus plants were placed at the green house. The plants were watered twice a day with $500 \mathrm{ml}$ of water for each session. The watering was done at $8.00 \mathrm{am}$ in the morning and at $5.00 \mathrm{pm}$ in the evening. The plants were fertilized with $10 \mathrm{mg}$ NPK blue once a week to produce highly rate of flower. Removal of the unwanted weeds was done manually by hand. The damaged stems or leaves were removed in order to prevent the diseases and pest from spreading to other plants.

The flowers were harvested after 3 months of planting. Stems bearing an average of 20 flowers with $50 \%$ open flowers were chosen as cut stems. The stem length was 14 $\mathrm{cm}$ in average. The harvest time was early in the morning, between 8 to 9 a.m, harvesting was done using sharp and sterile secateurs. The cut stems were transferred into a 
bucket filled with tap water and immediately transported to the laboratory. Then, the cut stems were recut under water to remove air embolism from the stems' end. As the cut $A$. leptopus were about $14 \mathrm{~cm}$ in average, $15 \mathrm{~mL}$ glass vial was used instead of vase. The vial measurement was 21 $\mathrm{mm}$ in diameter and $70 \mathrm{~mm}$ height. One cut stem was put into each vial containing $12 \mathrm{ml}$ vase solution. Then the vials' mouth were sealed with parafilm to minimize solution evaporation and to avoid contamination. The complete vase solution treatments with cut flowers were placed in the laboratory flower rack at room temperature of $26^{\circ} \mathrm{C}, 19.66 \mu \mathrm{mol} \mathrm{s}^{-1} \mathrm{~m}^{-2}$ light intensity and $69 \%$ of relative humidity.

\section{Vase Solution Treatment Preparation}

Vase solution treatments were prepared one day before harvesting the flowers. Overall, six treatments were involved in this study. They were Artificial Tap Water (ATW) as control, $100 \mathrm{mg} / \mathrm{L} \mathrm{SA}, 200 \mathrm{mg} / \mathrm{L} \mathrm{SA}, 300 \mathrm{mg} / \mathrm{L}$ $\mathrm{SA}, 100 \mathrm{mg} / \mathrm{L} \mathrm{SA}+2 \%$ sucrose, $200 \mathrm{mg} / \mathrm{L} \mathrm{SA}+2 \%$ sucrose and $300 \mathrm{mg} / \mathrm{L} \mathrm{SA}+2 \%$ sucrose. The ATW was prepared based on Van Meeteren et al. (1999) by mixing $0.1 \mathrm{~g} / \mathrm{L}$ calcium chloride $\left(\mathrm{CaCl}_{2}\right), 0.12 \mathrm{~g} / \mathrm{L}$ sodium carbonate $\left(\mathrm{Na}_{2} \mathrm{CO}_{3}\right)$ and $0.00125 \mathrm{~g} / \mathrm{L}$ copper (II) sulphate $\left(\mathrm{CuSO}_{4}\right)$.

\section{Vase Solution Uptake (VSU)}

The vases containing vase solution without the cut flowers were weighed by using electronic balance and were recorded daily during the vase life evaluation period

$\mathrm{VSU}=(\mathrm{St}-1-\mathrm{St}) /$ Initial Fresh Weight

$\mathrm{St}=$ weight of vase solution $(\mathrm{g})$ at $\mathrm{t}=$ day $1,2,3$, etc;

St-1 = weight of vase solution $(\mathrm{g})$ on previous day.

\section{Relative Fresh Weight $($ RFW)}

The fresh weight of $A$. leptopus was measured daily by using electronic balance. The original fresh weight after cutting the stems and before immersing in the solution

\section{Experimental Design}

The experimental design was a Complete Randomized Design (CRD). The parameters studied were divided into non-destructive and destructive test. The non-destructive tests measured were vase life, flower drop, relative fresh weight, vase solution uptake and $\mathrm{pH}$ with 5 replicates. Relative water content and petals colour were the destructive tests with 3 replicates for each parameter.

\section{Assessment and Data Collection Vase Life}

The vase life of cut flowers was assessed as the number of days to the wilting of flowers and the observation was done once a day (Soleimany-Fard et al., 2013). The vase life was terminated when the inflorescences showed wilting, colour fading and $50 \%$ flower drop. The vase life was marked as 1 for acceptable stems while the unacceptable stems was marked as 0 .

\section{Flower Drop}

Based on earlier observations, it was noted that $A$. leptopus experienced flower drop. Hence the amount of flower drops of cut A. leptopus flowers for each treatment was measured and recorded daily in units.

(Elhindi, 2012). The original weight of vase with the solution treatment before immersing the cut flowers was weighed. The equation to calculate VSU was according to Gebremedhin et al. (2013):

\section{(Equation 2)}

$$
\begin{aligned}
& \quad(\text { Vase weight }+ \text { cut flower })-(\text { vase weight })=\text { weight of cut flower } \\
& \mathrm{RFW}=\left(\mathrm{W}_{\mathrm{t}} / \mathrm{W}_{0}\right) \times 100 \\
& \mathrm{Wt}=\text { weight of stem }(\mathrm{g}) \text { at } \mathrm{t}=\text { day } 0,1,2 \text {, etc } \\
& \mathrm{W}_{0}=\text { weight of same stem }(\mathrm{g}) \text { at } \mathrm{t}=\text { day } 0
\end{aligned}
$$

treatment was measured (Asrar, 2012). The vase with the cut flowers was weighed together. Then the cut flowers were lifted up in order to measure weight of the vase. The RFW was calculated as follows (Hatamzadeh et al., 2012):

\section{Relative Water Content (RWC)}

Relative water content (RWC) of the flowers was determined at two day interval. For RWC evaluation, one gram of petals was weighed from the flowers and was considered as fresh weight $(\mathrm{FW})$. Then, the petals were placed between two layers of completely wet filter paper inside a petri dish and were sealed with parafilm. The petri dish was placed in the dark at room temperature for $24 \mathrm{~h}$. After $24 \mathrm{~h}$, the petals were weighed and this was considered as turgid weight (TW). The petals then were dried at $70^{\circ} \mathrm{C}$ in an oven for $24 \mathrm{~h}$. After $24 \mathrm{~h}$ drying, the petals were 
placed in a desiccator to cool down the sample for $5 \mathrm{~h}$. Then, the samples were reweighed and recorded as dry

$$
\mathrm{RWC} \%=(\mathrm{FW}-\mathrm{DW}) /(\mathrm{TW}-\mathrm{DW}) \times 100
$$

\section{Petal Colour}

The flowers were collected and evaluated at two day interval by using a Minolta Chroma Meter. The colour of the petals was measured collectively because the flowers were too small to be measured individually. Ten flowers were put in a small round plastic container with a diameter of $3 \mathrm{~cm}$ and height of $1 \mathrm{~cm}$. The data obtained from the Minolta Chroma Meter was recorded in the form of lightness $\left(\mathrm{L}^{*}\right)$ value, $\left(\mathrm{a}^{*}\right)$ value, $\left(\mathrm{b}^{*}\right)$ value. The changes in colour then were evaluated.

\section{pH}

The $\mathrm{pH}$ of the vase solution was measured using a $\mathrm{pH}$ meter and was measured only twice which was on day 0 (day initial) and final day of the vase life.

\section{Statistical Analysis}

All collected data were analysed by using Excel and IBM SPSS software. The data were subjected to one way ANOVA test to compare between treatments and control and then one way ANOVA repeated measure test to compare between days and further separated by Tukey test for least significance at $\mathrm{P}<0.05$ using SPSS software version 20. For $\mathrm{pH}$ analysis, Paired Sample T- test was used to compare between days, which were day initial and day final. weight (DW). The RWC was determined based on Talebi et al. (2013):

\section{Results and Discussion Vase Life}

(Equation 5)

The results showed that the application of different preservation treatments had significant effect on vase life $(\mathrm{p}<0.05)$ (Table 1). Based on Table 1, the longest vase life achieved for cut $A$. leptopus in this study was 6.8 days for cut stems treated with $200 \mathrm{mg} / \mathrm{L} \mathrm{SA}+2 \%$ sucrose. Increasing the SA amount to $300 \mathrm{mg} / \mathrm{L}$ either with or without sucrose seemed to reduce the vase life of the cut stems. This suggested that higher amount than $200 \mathrm{mg} / \mathrm{L}$ of $\mathrm{SA}$ is not favourable to extend the vase life of A. leptopus. However, no phytotoxicity effect was observed in the cut stems treated with $300 \mathrm{mg} / \mathrm{L}$ SA. Kumar et al. (2013) reported that high dose of SA which was $100 \mathrm{ppm}$ in Egyptian clover was found toxic for yield as it may reduce shoot and root length of germinating seed. The lowest vase life recorded was 2.6 days, for cut stems treated with 200 $\mathrm{mg} / \mathrm{L} \mathrm{SA}$. This study has proven that the combination of SA with sucrose had positive effect on the vase life since all treatments involved SA and sucrose; $200 \mathrm{mg} / \mathrm{L} \mathrm{SA}+$ $2 \%$ sucrose extended vase life, compared to treatments with SA alone and control. Hence this study provides a useful information that sucrose is crucial to extend the vase life of A. leptopus cut stems. Previous study stated that 200 and $300 \mathrm{mg} / \mathrm{L} \mathrm{SA}$ with $4 \%$ sucrose combination increased the vase life of cut Gerbera jamesonii up to 17 days (Bayat \& Aminifard, 2017). This could be due to SA's role as antimicrobial substance and ethylene inhibitor (Bayat \& Aminifard, 2017) which helped in delaying senescence in cut $A$. leptopus. SA with activated antioxidant enzymes can delays the senescence of cut flowers and lowering lipid production per oxidation resulting delay in senescence (Jamshidi et al., 2012). Combination of SA and sucrose increased vase life of cut A. leptopus as sucrose may increasing mechanical rigidity of the stem and induce cell wall thickening (Jafarpour et al., 2015). 
Table 1: Effect of different vase solution treatments on vase life of cut A. leptopus flower.

\begin{tabular}{cc}
\hline Treatments & Vase life (days \pm SE) \\
\hline Control (artificial tap water) & $3.2 \pm 0.20^{\mathrm{c}}$ \\
$100 \mathrm{mg} / \mathrm{L} \mathrm{SA}$ & $4 \pm 0.00^{\mathrm{bc}}$ \\
$200 \mathrm{mg} / \mathrm{L} \mathrm{SA}$ & $2.6 \pm 0.64^{\mathrm{c}}$ \\
$300 \mathrm{mg} / \mathrm{L} \mathrm{SA}$ & $2.8 \pm 0.64^{\mathrm{c}}$ \\
& $5.8 \pm 0.68^{\mathrm{ab}}$ \\
$100 \mathrm{mg} / \mathrm{L} \mathrm{SA}+2 \%$ sucrose & $6.8 \pm 0.20^{\mathrm{a}}$ \\
$200 \mathrm{mg} / \mathrm{L} \mathrm{SA}+2 \%$ sucrose & $6.6 \pm 0.40^{\mathrm{a}}$ \\
$300 \mathrm{mg} / \mathrm{L} \mathrm{SA}+2 \%$ sucrose & \\
\hline SA $=$ Salicylic acid. Values are expressed in mean \pm standard error for 5 replications $(\mathrm{n}=5)$. \\
Values with different superscript letter are significantly different at $\mathrm{p}<0.05$.
\end{tabular}

\section{Flower Drop}

The application of different preservation treatments showed significant effect $(\mathrm{p}<0.05)$ on flower drop of $A$. leptopus (Figure 1). Based on Figure 1, flower drop showed unspecific trend but it can be said that cut stems treated with $200 \mathrm{mg} / \mathrm{L} \mathrm{SA}+2 \%$ sucrose and $300 \mathrm{mg} / \mathrm{L} \mathrm{SA}$ $+2 \%$ sucrose were able to slow the rate of flower drop as compared to other treatments and control. Significantly high flower drop on day 1 was observed in cut stems treated with $200 \mathrm{mg} / \mathrm{L} \mathrm{SA}$ only. Ethylene production has been associated with flower or petal drop, irregular opening and premature death and also lead to shortening of vase life (Sudaria et al., 2017).
Marandi et al. (2011) reported that ethylene with high concentration could be an important factor in reducing cut flower longevity and enhancing senescence rate. However, no ethylene rate production was measured in this study. Hence it is very important to investigate the ethylene production in $A$. leptopus in the future in order to understand the underlying factors that promote flower drop in the cut stems. The combination of SA with sucrose showed positive effects by reducing flower drop possibly because sucrose provided energy to the cut flowers. 300 $\mathrm{mg} / \mathrm{L} \mathrm{SA}$ was reported to extend vase life of cut Alstroemeria peruviana until day 26 with minimum wilting and petal drop (Bayat \& Aminifard, 2017).

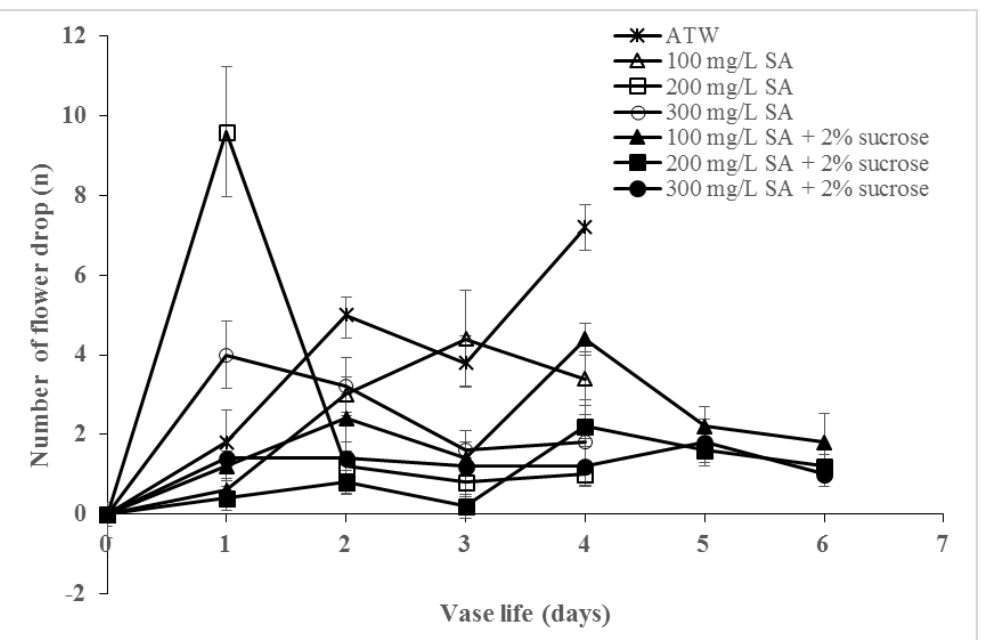

Figure 1: Effects of different preservation treatments on flower drop of cut A. leptopus flower. Values are expressed in mean \pm standard error for 5 replications $(n=5)$.

Vase Solution Uptake (VSU) 
Figure 2 shows that treatments $100 \mathrm{mg} / \mathrm{L} \mathrm{SA}+2 \%$ sucrose and $200 \mathrm{mg} / \mathrm{L} \mathrm{SA}+2 \%$ sucrose became the positive treatments as they maintained the cut stems' water uptake with slightly decreased trend until the end of vase life. Previous study showed that the combination of $4 \%$ sucrose with 200 and $300 \mathrm{mg} / \mathrm{L} \mathrm{SA}$ could increase water uptake in Rosa hybrida (Bayat \& Aminifard, 2017). For cut Gerbera flowers, $400 \mathrm{mg} / \mathrm{L} \mathrm{SA}+4 \%$ sucrose was identified to enhance uptake of vase solution (Sardoei \& Shahdadneghad, 2014). According to Dahal (2013), SA could reduce bacteria proliferation and therefore reduce xylem blockage and increase solution uptake while sucrose provided energy for cut flower to uptake the solution. The microbial propagules were able to cause physical plugging of the xylem vessels, disturbance of water uptake and the microbial itself may excrete toxic into vase solution that promoted senescence (Put \& Jensen, 1989). The low pH of SA was not important for solution uptake but it could reduce bacterial growth that prevented microbial blockage in cut stems while providing sucrose allowed more uptake of vase solution. Thus, the combination of sucrose and SA resulted in high rate of VSU by cut A. leptopus inflorescence.

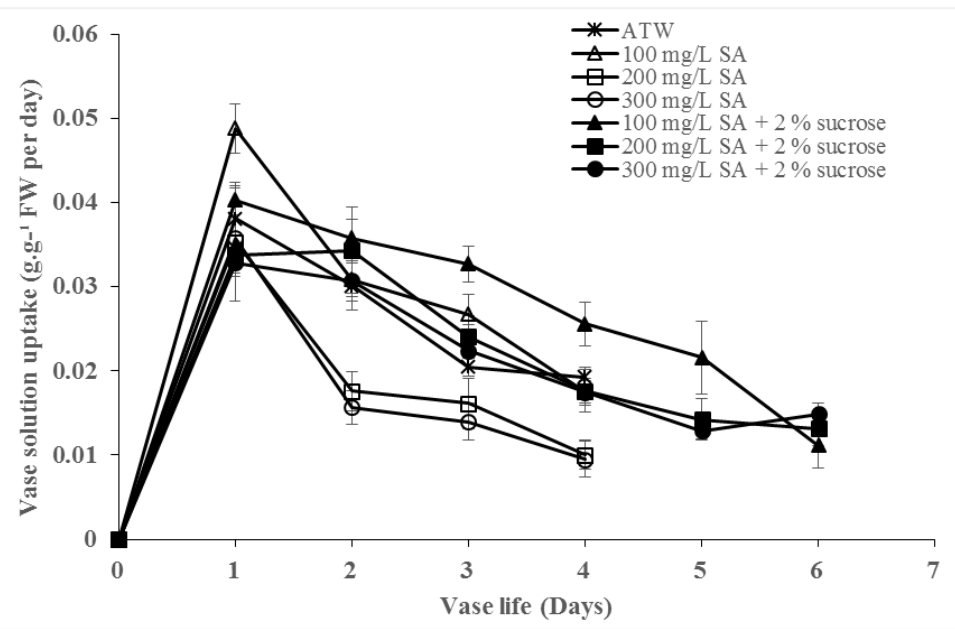

Figure 2: Effects of different preservation treatments on vase solution uptake of cut A. leptopus flower. Values are expressed in mean \pm standard error for 5 replications $(n=5)$.

\section{Relative Fresh Weight $($ RFW)}

The application of different preservation treatments on RFW showed significant effect $(\mathrm{p}<0.05)$ (Figure 3). As for relative fresh weight (RFW), $200 \mathrm{mg} / \mathrm{L} \mathrm{SA}+2 \%$ sucrose showed the highest RFW compared to control and other treatments along vase life (Figure 3). Sardoei \& Shahdadneghad (2014) also recorded that $800 \mathrm{mg} / \mathrm{L} \mathrm{SA}+$ $4 \%$ sucrose increased fresh weight of cut gerbera. Sucrose was reported to promote flower opening by increasing the osmotic pressure to flower opening and inhibiting ethylene production (Ichimura, 1998) whilst SA treatment only enhanced water absorption and increased fresh weight of cut chrysanthemum flowers (Zamani et al., 2011). From Figure 3, treatment $200 \mathrm{mg} / \mathrm{L} \mathrm{SA}+2 \%$ sucrose maintained the fresh weight of $A$. leptopus cut flowers along the vase life. The combination of SA and sucrose increased vase solution uptake (Figure 2) by the cut stems. It is very important for xylem to transport water and energy to the plant tissue in order to carry out metabolism (De Boer \& Volkov, 2003). Water and solute (sucrose) become the factor to determine turgor, driving plant cell expansion and contribute to plant form and function which involve stomata movements (Blatt et al., 2014). So, higher water content in the xylem indicates that the cut flowers are still alive with functioning cell tissue thus maintaining the fresh weight and petal relative water content. 


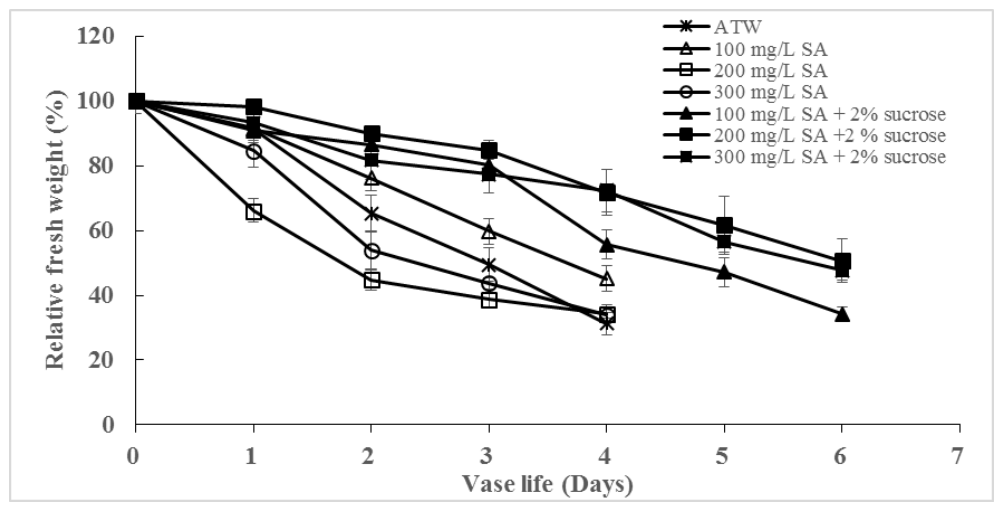

Figure 3: Effects of different preservation treatments on relative fresh weight of cut A. leptopus flower. Values are expressed in mean \pm standard error for 5 replications $(n=5)$.

\section{Relative Water Content (RWC)}

Based on Figure 4, the use of different preservation treatments had significant effect $(\mathrm{p}<0.05)$ on flower RWC. In most cut stems, RWC of flowers increased from day 0 to day 2 before decreasing from day 2 onwards. The RWC result aligned with the results of VSU and RFW where combination of SA and sucrose was beneficial for cut $A$. leptopus flowers. This RWC result also showed that SA treatment alone was not suitable for cut A. leptopus where the flowers' RWC dropped to $69 \%$, even lower than the flowers in control. As for cut stems in SA and sucrose solutions, treatment $200 \mathrm{mg} / \mathrm{L} \mathrm{SA}+2 \%$ sucrose could maintain the petals' turgidity compared to other treatments and control until end of vase life. Petals of cut flowers are the major ornamental parts and their turgidity is an indicator for flower freshness. The turgidity of petals depends largely on water uptake and maintenance in treatments used (Bayat \& Aminifard, 2017). RWC is a method to measure actual water status in leaves or petals without the need of any special equipment (Sade et al., 2015). Besides, RWC provides a measurement of the 'water deficit' and may indicate a degree of stress of the petals. In Lilium asiaticum, 200 or $300 \mathrm{mg} / \mathrm{L} \mathrm{SA}+4 \%$ sucrose displayed the highest RWC while the combination of sucrose with $200 \mathrm{mg} / \mathrm{L}$ SA showed an increase in petal water content of Gerbera jamesonii (Bayat \& Aminifard, 2017). Thus, for this study, it was suggested that similar role of $200 \mathrm{mg} / \mathrm{L} \mathrm{SA}+2 \%$ sucrose be applied, which resulted in the maintenance of the structure of the flowers and the reduction of flower drop. Since the RWC was affected by the vase solution uptake, increase in water uptake by the cut $A$. leptopus flowers increased the petal RWC and increased the RFW of the cut flower as well. According to the American Society of Plant Biologists (2014), vascular plants that consisted structures enabled them to transport water long distances with little input of energy. Besides, water and solute like sucrose become the factor to determine turgor, drive plant cell expansion and contribute to plant form and function which involve stomata movements (Blatt et al., 2014). 


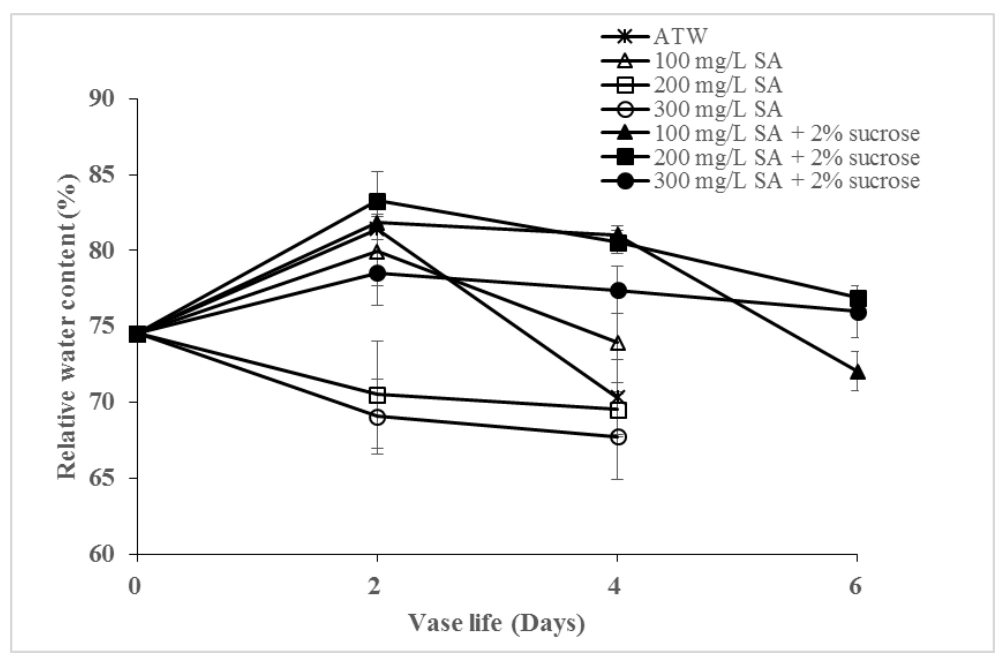

Figure 4: Effects of different preservation treatments on relative water content of cut A. leptopus flower. Values are expressed in mean \pm standard error for 3 replications $(n=5)$.

\section{Petal Colour}

Based on Figure 5a, the application of different preservation treatments on $\mathrm{L}^{*}$ value showed significant effect $(\mathrm{p}<0.05)$ on day 2 . The result of colour $\left(\mathrm{L}^{*} \mathrm{a}^{*} \mathrm{~b}^{*}\right)$ for treatments containing $200 \mathrm{mg} / \mathrm{L} \mathrm{SA}+2 \%$ sucrose and $300 \mathrm{mg} / \mathrm{L} \mathrm{SA}+2 \%$ sucrose displayed the lowest in $\mathrm{L}^{*}$ value and highest in $\mathrm{a}^{*}$ value as compared to other treatments (Figure 5). For $b^{*}$ value, both treatments 100 $\mathrm{mg} / \mathrm{L} \mathrm{SA}+2 \%$ sucrose and $200 \mathrm{mg} / \mathrm{L} \mathrm{SA}+2 \%$ sucrose showed the lowest of value compared to other treatments. The low $\mathrm{L}^{*}$ value indicated low of lightness so the colour of A. leptopus flowers still maintained the bright pink colour. The high value of $\mathrm{L}^{*}$ indicated that the pink $A$. leptopus flowers were going senescence, showing discolouration petals symptom (dull pink). Greener-redder colour was measured via $a^{*}$ value. The lower $a^{*}$ value indicated that the flower was going senescence, changing from bright pink colour to dull pink. This shows that the lower the $\mathrm{a}^{*}$ value, the more decrease in pink colour of $A$. leptopus flower was observed. The higher $\mathrm{a}^{*}$ value indicated the colour near to red portion which means the pink colour of the flower was still maintained. Based on colour chart $L^{*} a^{*} b^{*}$, the higher $b^{*}$ value indicated that the petals became yellowish in colour, showing senescence of the petals. The lower $\mathrm{b}^{*}$ indicated that the petals of $A$. leptopus were still fresh and the bright pink colour was maintained. Discolouration and colour fading were the main reasons for termination of vase life in most cut flowers and important factors in determining display quality of cut flowers (Rani \& Singh, 2014). In this study, treatments containing $200 \mathrm{mg} / \mathrm{L} \mathrm{SA}+2 \%$ sucrose and 300 $\mathrm{mg} / \mathrm{L} \mathrm{SA}+2 \%$ sucrose showed the ability to maintain the colour of $A$. leptopus cut flowers. 

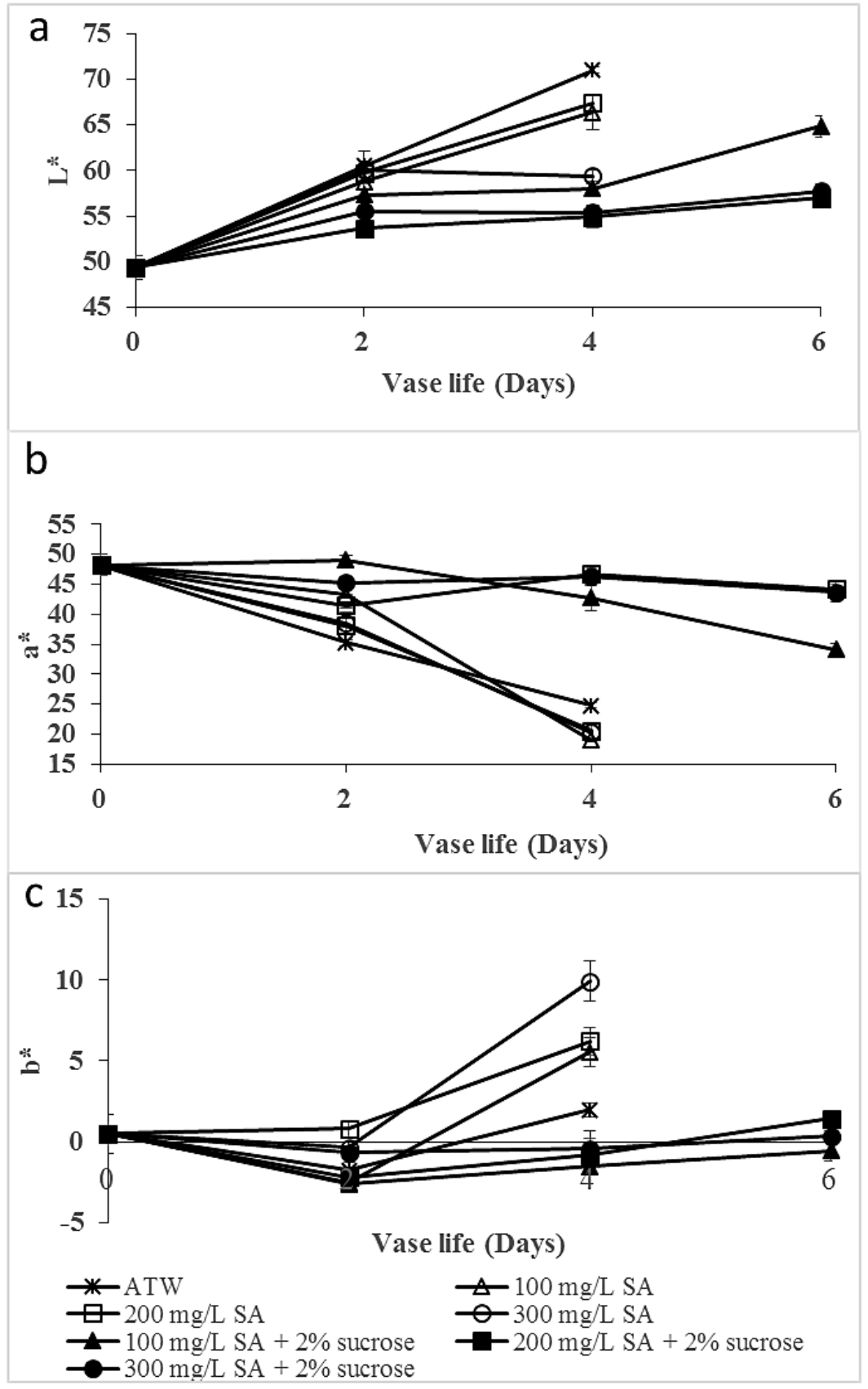

Figure 5: Effects of different preservation treatments on colour (a: $\mathrm{L}^{*}, \mathrm{~b}: \mathrm{a}^{*}$ and $\left.\mathrm{c}: \mathrm{b}^{*}\right)$ value of cut A. leptopus flowers. Values are expressed in mean \pm standard error for 3 replications $(n=5)$.

\section{$p H$}

The $\mathrm{pH}$ result indicated that there was significant difference $(\mathrm{p}<0.05)$ between day initial and day final for all treatments except for $100 \mathrm{mg} / \mathrm{L} \mathrm{SA}$ (Figure 6). Overall, the $\mathrm{pH}$ of control and $200 \mathrm{mg} / \mathrm{L}$ SA solutions showed significant decrease in $\mathrm{pH}$ between day initial and day final. The other treatments showed significant increase in
$\mathrm{pH}$ value against time except for $100 \mathrm{mg} / \mathrm{L} \mathrm{SA}$ treatment. The lower value of $\mathrm{pH}$ at day final compared to day initial indicated that the $\mathrm{pH}$ condition of vase solution was not favourable for the cut flowers to extend the longevity as in control and $200 \mathrm{mg} / \mathrm{L} \mathrm{SA}$. This might be due to the cut $A$. leptopus that released other compound such as endogenous $\mathrm{SA}$ that might lower the $\mathrm{pH}$ value of vase solution when in a stress condition. War et al. (2011) stated that SA was 
plant phenolic hormone which played an important role in the induction of plant defence against a variety of biotic and abiotic stresses through physical, morphological and biochemical mechanisms. Besides, the higher $\mathrm{pH}$ value at day final compared to day initial indicated that the $\mathrm{pH}$ condition of vase solution between the range of 2.7 to 3.3 of $\mathrm{pH}$ value was favourable for the cut flowers to extend the longevity like the $\mathrm{pH}$ in treatments $100 \mathrm{mg} / \mathrm{L}+2 \%$ sucrose, $200 \mathrm{mg} / \mathrm{L} \mathrm{SA}+2 \%$ sucrose and $300 \mathrm{mg} / \mathrm{L} \mathrm{SA}+$ $2 \%$ sucrose. During vase treatment, the plant might absorb carbon dioxide from the vase solution and removed it from water causing the $\mathrm{pH}$ to increase (Boumis, 2018). This indicated that the cut flowers were still healthy and alive and undergoing physiological metabolism. According to Edaphic Scientific (2016), carbon dioxide that dissolved in water would form carbonic acid and then dissociate into biocarbonate and hydrogen ions. The hydrogen ion concentration in a solution became the indicator to measure the $\mathrm{pH}$.

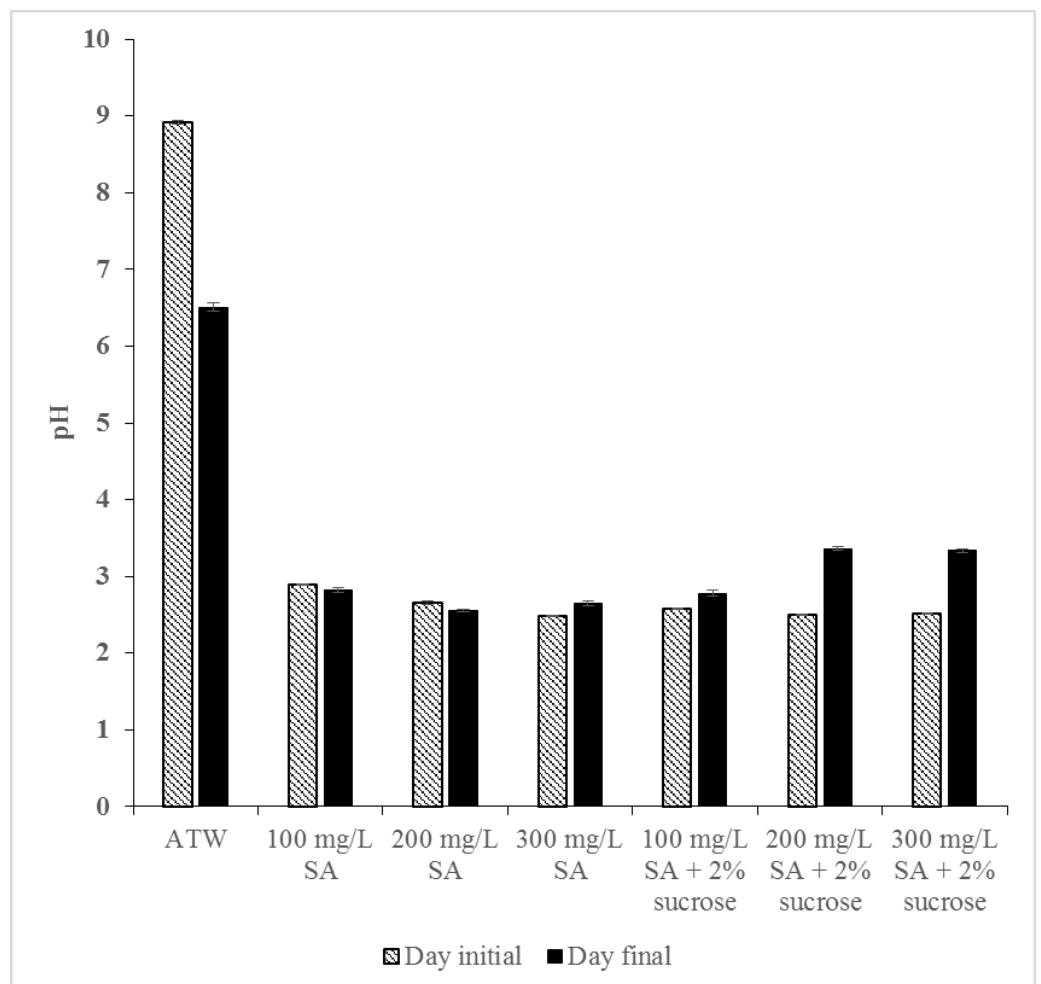

Figure 6: Effects of different preservation treatments on $\mathrm{pH}$ of vase solution treatment of cut A. leptopus flowers. Values are expressed in mean \pm standard error for 5 replications $(n=5)$.

\section{Conclusion}

In conclusion, the combination of $200 \mathrm{mg} / \mathrm{L} \mathrm{SA}+2 \%$ sucrose was determined as the best vase solution treatment to maintain the quality of cut A. leptopus stems in this study. Adding $200 \mathrm{mg} / \mathrm{L} \mathrm{SA}+2 \%$ sucrose into vase solution maintained the vase solution $\mathrm{pH}$ below 4. Acidic water improved vase solution uptake by the cut $A$. leptopus stems which led to sustainment in turgidity of the flower petals. Concurrently, the cut stems maintained their fresh weight and colour, and experienced less flower drop. The positive effects of the treatment allowed the cut stems to maintain the vase life 1.6 fold longer than the control. Therefore it is suggested that $200 \mathrm{mg} / \mathrm{L} \mathrm{SA}+2 \%$ sucrose has potential as postharvest vase solution treatment for cut A. leptopus flowers. Since this study is the first research focusing on vase life of cut A. leptopus, further studies should be continued to determine the requirements of cut A. leptopus towards their establishment as cut flowers for floral arrangement. One of the priorities is to investigate the cut A. leptopus stem reactions against ethylene and ethylene production in relation to flower drop.

\section{Acknowledgements}

This research was supported by School of Food Science and Technology, Universiti Malaysia Terengganu.

\section{References}

Adjaloo, M. K., Ankomah, A. A., Yeboah-Gyan, K. \& Dzomeku, B. M. (2015). Nectar production dynamics in two melliferous plant species. Genetics and Plant Physiology, 5(2), 145-161. 
American Society of Plant Biologists. (2014). Plant-Water Relations (1): Uptake and Transport. Retrieved from http://www.plantcell.org/content/26/1/tpc.114.tt0114, 1 May 2018.

Asrar, A-W. A. (2012). Effects of some preservative solutions on vase life and keeping quality of snapdragon (Antirrhinum majus L.) cut flowers. Journal of the Saudi Society of Agricultural Sciences, 11(1), 29-35.

Balasubramani, G., Deepak, P., Sowmiya, R., Ramkumar, R. \& Perumal, P. (2014). Antigonon leptopus: A potent biological source for extermination of fish bacterial pathogens Providencia and Aeromonas. Natural Product Research, 29(10), 958-960.

Baxter County Master Gardener. (2005). Principles of Floral Arrangement. University of Arkansas, Division of Agriculture, Pp 1-18.

Bayat, H. \& Aminifard, M. H. (2017). Salicylic acid treatment extends the vase life of five commercial cut flowers. Electronic Journal of Biology, 13(1), 6772 .

Blatt, M. R., Chaumont, F. and Farquhar, G. (2014). Focus on water. Plant Physiology, 164(4), 1553-1555.

Boumis, R. 2018. Effect of Aquarium Plants on $\mathrm{pH}$. Retrieved from http://animals.mom.me/effectaquarium-plants-ph-5049.html, 26 April 2018.

Burke, J. M. \& DiTommaso, A. (2011). Corallita (Antigonon leptopus): Intentional introduction of a plant with documented invasive capability. Invasive Plant Science Management, 4(3), 265-273.

Butt, S. J. (2005). Extending the vase life of roses (Rosa hybrida) with different preservatives. International Journal of Agriculture and Biology, 7(1), 97-99.

Dahal, S. (2013). Postharvest handling of cut-flower rose. Technical Report, Institute of Agriculture and Animal Sciences, Nepal.

De Boer, A. H. \& Volkov, V. (2003). Logistics of water and salt transport through the plant: structure and functioning of the xylem. Plant Cell and Environment, 26(1), 87-101.

De, L. C., Vij, S. P. \& Medhi, R. P. (2014). Post-harvest physiology and technology in orchids. Journal of Horticulture, 1(102), 1-9.
Edaphic Scientific (2016). What do $\mathrm{pH}$ and photosynthesis have in common?. Retrieved from http://www.edaphic.com.au/what-do-ph-andphotosynthesis- have-in- common/,22 April 2018.

Elhindi, K. M. (2012). Evaluation of several holding solutions for prolonging vase-life and keeping quality of cut sweet pea flowers (Lathyrus odoratus L.). Saudi Journal of Biological Sciences, 19(2), 195202.

Gebremedhin, H., Tesfaye, B., Mohammed, A. \& Tsegay, D. (2013). Influence of preservative solutions on vase life and postharvest characteristics of rose (Rosa hybrid) cut flowers. International Journal for Biotechnology and Molecular Biology Research, 4(8), 111- 118.

Hatamzadeh, A., Hatami, M. \& Ghasemnezhad, M. (2012). Efficiency of salicylic acid delay petal senescence and extended quality of cut spikes of Gladiolus grandifloral cv 'wing sensation'. African Journal of Agricultural Research, 7(4), 540-545.

Ichimura, K. (1998). Improvement of postharvest life in several cut flowers by the addition of sucrose. Japan Agricultural Research Quarterly, 32, 275-280.

Jafarpour, M., Golparvar, A.R., Askarikhorasgani, O. \& Amini, S. (2015). Improving postharvest flowers using natural and chemical preservatives. Journal of European Agriculture, 16(2), 199-211.

Jamshidi, M., Hadavi, E. \& Naderi, R. (2012). Effect of Salicylic acid and Malic acid on vase life and bacterial and yeast populations of preservative solution in cut Gerbera flowers. International Journal of AgriScience, 2(8), 671-674.

Kumar, B., Singh, Y.S., Ram, H. \& Sarlach, R.S. (2013). Enhancing seed yield and quality of Egyptian clover (Trifolium alexandrinum L.) with foliar application of bio-regulators. Field Crops Research, 146(2013), 25-30.

Marandi, R.J., Hassani, A., Abdollahi, A. \& Hanafi, S. (2011). Improvement of the vase life of cut gladiolus flowers by essential oils, salicylic acid and silver thiosulfate. Journal of Medicinal Plants Research, 5(20), 5039-5043.

Nazar, R., Umar, S. \& Khan, N.A. (2015). Exogenous salicylic acid improves photosynthesis and growth through increase in ascorbate-glutathione 
metabolism and $\mathrm{S}$ assimilation in mustard under salt stress. Plant Signaling and Behaviour, 10(3). doi:10.1080/15592324.2014.1003751

Put, H. M. C. \& Jansen, H. W. (1989). The effects on the vase life of cut Rosa cultivar 'Sonia' of bacteria added to the vase water. Scientia Horticulturae, 39(1989), 167-179.

Rani, P. \& Singh, N. (2014). Senescence and postharvest studies of cut flowers: A critical review. Pertanika Journal of Tropical Agricultural Science, 37(2), 159201.

Ranjan, P. \& Tripathi, K. (2015). Antigonon leptopus: An review. European Journal of Pharmaceutical and Medical Research, 2, 473-483.

Sade, N. Galkin, E. \& Moshelion, M. (2015). Measuring Arabidopsis, tomato and barley leaf relative water content (RWC). Bio-protocol, 5(8), 1-4.

Sardoei, S. \& Shahdadneghad, M. (2014). Interaction effect of sucrose and salicylic acid on vase life of cut Gerbera flowers. International Journal of Biological Sciences, 1(1), 60-65.

Sathi, S. \& Habibur, R.C. (2013). Pharmacognostic and anatomical studies of Antigonon leptopus Hook. and Arn.: a promising medical climber. International Journal of Research in Ayurveda and Pharmacy, 4(2), 186-191.
Soleimany-Fard, E., Hemmati, K. \& Khalighi, A. (2013). Improving the keeping quality and vase life of cut Alstroemeria flowers by pre and post-harvest salicylic acid treatments. Notulae Scientia Biologicae, 5(3), 364-370.

Sudaria, M. A, Uthairatanakij, A. \& Nguyen, H. T. (2017). Postharvest quality effects of different vaselife solutions on cut rose (Rosa hybrida L.). International Journal of Agriculture, Forestry and Life Science, $1(1), 12-20$.

Talebi, S.F., Mortazavi, S.N. \& Sharafi, Y. (2013). Extending vase life of rosa (Cv. 'Sensiro') cut flowers with nitric oxide. International Journal of Agronomy and Plant Production, 4(6), 1178-1183.

Van Meeteren, U., Van Gelder, H. \& Van Ieperen, W. (1999). Reconsideration of the use of deionized water as vase water in postharvest experiments on cut flowers. Postharvest Biology and Technology, 17(3), 175-187.

War, A. R., Paulraj, M. G., War, M. Y. \& Ignacimuthu, S. (2011). Role of salicylic acid in induction of plant defense system in chickpea (Cicer arietinum L.). Plant Signaling and Behaviour, 6(11), 1787-1792.

Zamani, S., Hadavi, E., Kazemi, M. \& Hekmati, J. (2011). Effects of some chemical treatments on keeping of chrysanthemum cut flowers. World Applied Sciences Journal, $\quad$ 12(11), 1962-1966. 